\title{
WAO: niet alle oude schoenen zijn slecht!
}

\author{
J.J.M. Besseling
}

$\mathrm{H}$ et kan $\mathrm{u}$ niet ontgaan zijn dat er weer nieuw beleid gemaakt wordt rond de WAO. In de voorstellen die worden ontwikkeld, wordt zwaar ingezet op het ontzeggen van de toegang tot de WAO. Volgens de voorstellen zou een deel van de huidige volledig arbeidsongeschikten in de toekomst geen recht hebben op een WAO-uitkering. Ook alle gedeeltelijk arbeidsongeschikten zullen volgens die plannen geen recht meer hebben op een publiek gefinancierde arbeidsongeschiktheidsuitkering.

$\mathrm{H}$ et gemak waarmee de gedeeltelijke W AOuitkering wordt geschrapt, is verontrustend. Veel gedeeltelijk arbeidsongeschikten werken. $K$ ort na de claimbeoordeling werkt ongeveer driekwart van de gedeeltelijk arbeidsongeschikten. D e gedeeltelijke WAO-uitkering lijkt hiermee één van de belangrijkste arbeidsmarktinstrumenten te zijn om arbeidsgehandicapten aan het werk te houden in de lijn zoals Veldkamp het destijds voor ogen stond.

$\mathrm{H}$ et is niet uitgesloten dat het succes van de gedeeltelijke WAO-uitkering als arbeidsmarktinstrument niet het resultaat is van bewust beleid, maar juist van een uitvoeringspraktijk die een deel van het nieuwe beleid destijds van TBA heeft genegeerd. In het schattingsbesluit is toentertijd geen aandacht geschonken aan het feit dat de schatting de reïntegratie kan ondersteunen. $\mathrm{H}$ et schattingsbesluit stelt dat uitgegaan moet worden van de theoretische verdiencapaciteit tenzij de gerealiseerde verdiencapaciteit hoger is.
Bij strikte uitvoering van dit beleid kan er spanning ontstaan tussen het schattingsbesluit en de reïntegratietaak, als een poging tot reïntegratie gefrustreerd wordt door de hoogte van de theoretische schatting. De indruk bestaat dan ook dat in de praktijk bij gedeeltelijke arbeidsongeschiktheid met de schatting veelal het reïntegratieproces wordt ondersteund en dat het hiermee afwijkt van het formele beleid van TBA dat destijds ook gericht was op het terugdringen van het beroep op de W AO. H et L isv heeft vorig jaar T N O Arbeid opdracht gegeven om onderzoek te doen naar deze uitvoeringspraktijk. Recent C tsv-onderzoek geeft aan dat binnen de sector Overheid de claimbeoordeling zeer vaak ondersteunend is voor het realiseren van de reïntegratietaak door het hanteren van een urenbeperking en het toekennen van een gedeeltelijke WAOuitkering, 1 al wekken de getallen de indruk dat hier in veel gevallen geen sprake is van een beoordeling op medische gronden.

D e uitvoeringspraktijk sluit hiermee echter wel aan bij de grondgedachte destijds van de WAO zoals Veldkamp die voor ogen had: de WAO als activerend arbeidsmarktinstrument. $\mathrm{H}$ opelijk houden de beleidsmakers ook deze doelstelling voor ogen én de positieve kanten van het huidige WAO-stelsel.

1. Giezen AM van der, Fiseler JG, N ool JW, Ramakers AF. De uitvoering van de WAO door USZO. Ctsv, Zoetermeer, 2001.

Onderzoek: A gressie en pressie in de praktijk van de bedrijfsarts $T$. de M artines

Onderzoek: $L$ ongaandoeningen en werkgebonden risicofactoren bij varkenshouders

J.W.J . van der G ulden, P.F.J. Vogelzang, C.P. van Schayck, H.Th.M . Folgering

Opinie: Voorbeelden: E en hulpmiddel om de ernst van de beperkingen te beoordelen J. Spanjer 109

Agenda

Voor de praktijk: Dilemma voor de bedrijfsarts: Verwijzing verplicht?

M .J . K elder, A.N.H. W eel, A. W iersma, J J . L. van der K link

Arbocuratieve samenwerking: $\mathrm{H}$ uisartsen en bedrijfsartsen in opleiding leren actief

samenwerken in de praktijk A.P. N auta, H.C. Faddegon, J.W .P.M. Peeters

Arbocuratieve samenw erking: $D$ e $G$ roningse aanpak van handeczeem. E en samenwerkingsproject tussen huis- en bedrijfsarts en medisch specialist M.E.S. P oulssen-M estrom 